\title{
原著論文
}

\section{糖尿病患者のソーシャル・サポートシステムの構築に向けた ネットワーク上でのコミュニケーションへの影響要因の分析}

\author{
藤永 新子*, 東 ますみ**, 石橋 信江 ${ }^{* * *}$, 西村 治彦*** \\ * 四條畷学園大学, $* *$ 神戸女子大学, ${ }^{* * *}$ 兵庫県立大学大学院
}

\author{
Analysis of Influencing Factors on the Network Communication \\ for the Purpose of Constructing a Social Support System \\ for Diabetic Patients
}

\author{
Shinko FUJINAGA*, Masumi AZUMA**, Nobue ISHIBASHI*** and Haruhiko NISHIMURA*** \\ * Shijonawate Gakuen University, 6-45 Gakuen-machi, Daito, Osaka 574-0001, Japan \\ ** Kobe Women's University, 4-7-2 Minatojima-naka,Chuo-ku, Kobe, Hyogo 650-0046, Japan \\ *** University of Hyogo, 7-1-28 Minatojima-minami, Chuo-ku, Kobe, Hyogo 650-0047, Japan
}

\begin{abstract}
The purpose of this study is to analyze the influential factors on a diabetic patients' communication through the prototype developed to construct a social support system among diabetic patients who use ICT. The authors conducted semi-structured interviews with 31 patients who had used the system for one year. The results showed that forming relationships through their exchanging of posted messages affected their communication. Furthermore, it became a place to obtain information about selfmanagement that one could not acquire by himself/herself. On the other hand, not being able to know the other users' conditions, the difficulty of joining in others' dialogues, the hesitance of sending information and the hassles of describing their thoughts using ICT also affected the network communication. It is necessary to build a communication that corresponds with diabetic patients' interests and to examine methods that will help support interactive communication.
\end{abstract}

Keywords : Diabetes patients, Network, Communication, Self-management, Social support system

\section{1. は じめに}

近年，糖尿病患者に対する自己管理支援として医療者だけ でなく，同病者による支援（ピア・サポート）の有用性が報告 されている $[1]$. 糖尿病患者によるピア・サポートは, 特に食事 や運動といった治療遂行に関連した同病者の体験を基盤にし た支援が有効であり [2], 日々の自己管理を支え, 病気の不 安や, やる気の低迷といった心理的問題を軽減するといわれ ている [3]. 一方で, ピア・サポートの場となりうる患者会 へは, 40～50歳代の患者は, 仕事による制約や, 参加者のほ とんどが高齢者であるため参加しにくいことが報告されてい る [4].このように, 同病者の支援は, 自己管理の継続に重要 な要素と認知されながら, 実際には, すべての患者が同病者 による支援を受けられているわけではなく，時間や状況の制 約が問題となっている. これらの問題を解決する方法として, 近年, 時間や状況に影響を受けにくいメールや電話, 郵送な どの通信媒体を利用し，多くの支援が行われている $[5,6]$.

欧米では，ピア・サポートを病者の持つソーシャル・サポー 卜支援の重要な一つと位置づけ, ピア・サポーターと協働し たプログラムが導入され [7]，対面式だけでなく電話によ る同病者支援が，医療者の支援よりも有用であることが示さ れている $[8]$. しかし，わが国では同病者による支援を，
重要なソーシャル・サポート資源として位置づける迄には 至っていないのが現状である $[5,9]$.

同病者による支援では，ソーシャル・サポートを強化した グループ参加による通信制, 報償制の減量プログラムが あり，他者との関係によって作用の程度の差はあるものの， ソーシャル・サポートの強化が生活習慣の改善や実践の後押 しに効果的に作用すると報告されている [10]. また, 糖尿 病患者へのソーシャル・サポートの調査では, 患者の負担感 が強い時こそ，その効果が発揮されるといわれている [11] ことから, 他者との関係や状況によって, ソーシャル・サポー トの効果に相違があるといえる。

これらのことから，時間や状況に制約されず，いつでも誰 でも，同病者同士が支え合える支援は，医療者の支援を補完 する実用的な支援になるのではないかと考えた。

情報通信技術 (Information and Communication Technology: 以下 ICT と称す）を利用した参加者同士の交流の場として, チャットやフェイスブック, 掲示板など数多くのコミュニ ティが存在する。 その中で掲示板は, 面識のない者同士の社 会的ネットワークを通じて, それまで知りえなかった有用な 情報が得られる可能性があり，さらに関心をもつ事柄につい て議論することにより, 知識の進化や創発も期待できるとい われている [12]. そこで, 糖尿病を持つ患者同士の交流が できる場として, 揭示板機能を利用したソーシャル・サポー 
トシステム「糖尿病応援サイト」を設計した，そして，本格 的導入に向けて, プロトタイプを用いた同病者間のコミュニ ケーションを 1 年間実施した。一面識もなく背景も異なる 同病者同士が, どのようなコミュニケーションを行っている のか, 日常的に遭遇する多彩な場面に扔いて, 闘病生活の支 えや問題解決のツールとなりうるのか. それらを検討にする ことは, 時間や状況に制約のある糖尿病患者への新たな支援 につながるのではないかと考えた.

\section{2. 研 究目 的}

本研究の目的は, ICTを用いた糖尿病患者間のソーシャ ル・サポートシステムの本格的導入に向けて，そのプロト夕 イプの「糖尿病応援サイト」の運用を通して, 糖尿病患者同 士がネットワーク上でどのようなコミュニケーションを行っ ていたのかを分析し, 今後の効果的運用のための知見を得る ことである.

\section{3. ソーシャル・サポートシステム「糖尿病応援サイト」 の概要}

「糖尿病応援サイト」は，Free Webのサーバを利用し， WordPress3.5, PHP5.4.8, MySQL5.5.28, BuddyPress1.6.2 を用いて設計した。

「糖尿病応援サイト」は, 図 1 に示すように, 自己管理に関 する内容を限定した「食事」·「運動」·「くすり」·「自己管理へ の思い」のコンテンッと，日々の様子など自由に書き込める 「サイト広場」のコンテンツを設け, 同病者同士が非対面で コミュニケーションを行うものである.さらにお互いを知らない ことによるコミュニケーションに考慮し, 年代や性別, 糖尿病 歴，自己管理の現状など個人が把握できる「プロフィール」 のコンテンッを作成した。そして，本人に似せた似顔絵を表 示し，ハンドルネームを用いるようにした。投稿画面を図2

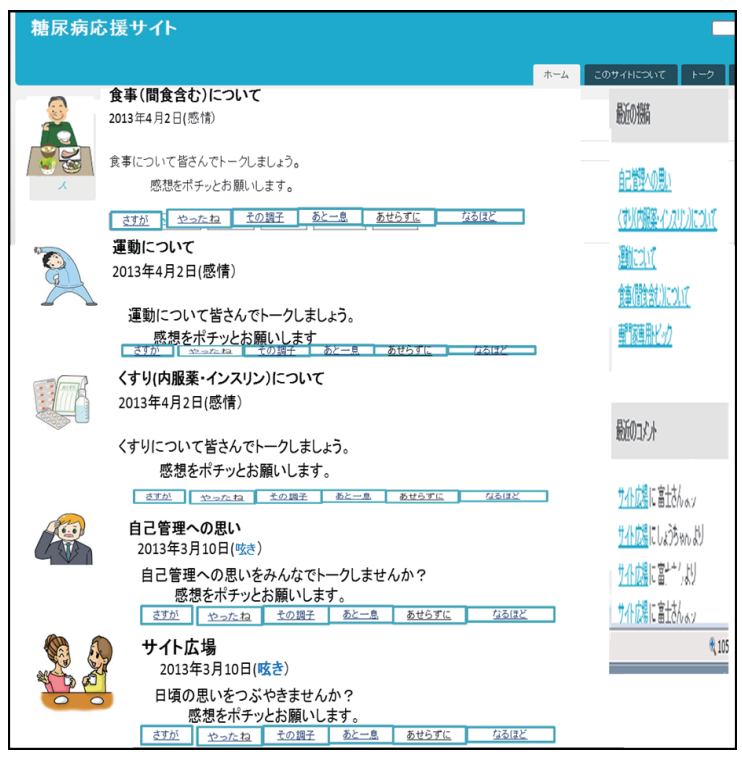

図 1 「糖尿病応援サイト」のコンテンツ画面

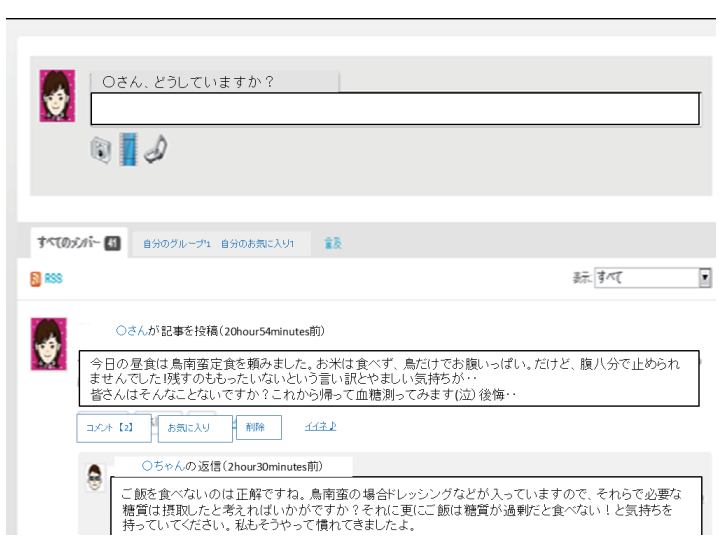

図2 投稿画面のスクリーンショット

に示す，投稿した記事に返信があった場合は，あらかじめ設 定しているアドレスに返信を知らせるメールが届くことで, リアルタイムにコミュニケーションがつながる仕組みである.

「糖尿病応援サイト」では，患者同士による情報に間違い がないか, 専門家 (栄養士・理学療法士, 看護師, 薬剤師) が同時に閲覧し，正当性を確保した。使用機器は，研究用に 貸し出すタブレット型端末か患者自身のパソコンとした.

\section{4. 研 究 方 法}

非対面のソーシャル・サポートシステムを利用して, 対象 者がどの様にコミュニケーションを行っていたのか，意見交 換や情報共有の場となっているのか, 利用において感じた思 いや態様などをボトムアップに捉えるために，対象者の収集 データの質的側面に主眼を置いた分析方法である質的帰納的 アプローチ法を用いた $[13,14]$.

\section{1 研究対象}

機縁的リクルートにより選定した糖尿病患者会のない医療 施設の代表者に，研究目的・方法を説明し，3施設からの 調査協力を得た。同意の得られた施設の代表者に，外来に通 院している 2 型糖尿病患者のうち認知症やうつ病がなく, タブレット型端末が使用可能な対象者を選定してもらった。 対象者の外来受診日に，研究者が研究内容を説明し，同意の 得られた 33 人を対象にした。

\section{2 調查方法}

（1）基本的属性（年齢 - 性別 - 職業 - 糖尿病歴 - 治療内容), 自己管理状況 (HbA1c·BMI)，一般的なソーシャルネッ トワーキングサービス (social networking service : 以下 SNS と称す）の利用の有無, ソーシャル・サポートシス テムの利用状況（投稿回数と閲覧回数）を調査した.

（2） 2013 年から 1 年間システムを利用した対象者に,「糖尿 病応援サイト」において，情報交換や思いの共有等の コミュニケーションをどのように行っていたのか，投稿 のしにくさはなかったのかを中心に，半構成的面接を 一人 30 分から 60 分程度実施した。面接内容は対象者の 
許可を得て録音し, 許可の得られなかった対象者は, 承諾を得て面接時にメモを取った。インタビュー日を 調整できない場合は，同じ質問項目を書面にし，郵送 により回答を求めた.

\section{3 分析方法}

対象者の半構成的面接から得られた内容を逐語録に起こ し，ネットワーク上での情報交換や思いの共有等のコミュニ ケーションに関連する部分について読み取った。次に，対象 者ごとの語りから, 関連した内容を中心に抽出し, 1つの意 味ごとに切り取り, 解釈し, コード化した。コードを類似性 と相違点を検討しながらサブカテゴリー化し，さらにサブカ テゴリー間の相互関連性を検討し，類似した内容のまとまり をカテゴリー化した。データの信頼性を高めるために，質的 研究に精通している研究者より分析結果について, スーパー バイズを受け，妥当性を確保した。

\section{4 倫理的配慮}

研究協力が得られた施設に対象者の選定を依頼し, 研究説 明を聞くことに対して了解の得られた対象者に, 研究への協 力は自由意志であること, 研究に協力しない場合や, 途中で 参加を中止することが可能であること, 研究によって得られ たデー夕は匿名性の保持に留意し, 本研究の目的以外は使用 しないこと, 研究成果の公表の際にも, 個人情報の保護には 細心の注意を払うことを説明し，書面にて同意を得た，参加 者には，専門家が閲覧することに関しても口頭と書面で同意 を得た。専門家には，個人情報の取り扱いに関して誓約書を 取り交わした。

なお, 本研究は兵庫県立大学大学院応用情報科学研究科研 究倫理委員会の承認を得て行った。

\section{5. 結 果}

\section{1 対象者の概要}

対象者は，途中で「糖尿病応援サイト」を中断した 2 人を 除いた 31 人で, 平均年齢 $58.3 \pm 9.3(\mathrm{SD})$ 歳で, 50 歳〜 59 歳 $38.7 \%$ で一番多く, 次いで 60 歳〜69歳 35.5\%であった。 病歴は 10 年以上が $51.6 \%$, 次いで 5 年〜 10 年未満が $22.6 \%$ であった (表1参照)。就業率は $57.6 \%$, 平均 $\mathrm{HbA} 1 \mathrm{c}$ は6.7\%,

表1 対象者の概要

\begin{tabular}{|c|c|c|c|}
\hline \multicolumn{2}{|r|}{ 項目 } & 人 & $\%$ \\
\hline \multirow[t]{5}{*}{ 年齢 } & $30 \sim 39$ 歳 & 1 & $3.2 \%$ \\
\hline & $40 \sim 49$ 歳 & 4 & $12.9 \%$ \\
\hline & $50 \sim 59$ 歳 & 12 & $38.7 \%$ \\
\hline & $60 \sim 69$ 歳 & 11 & $35.5 \%$ \\
\hline & 70～79歳 & 3 & $9.7 \%$ \\
\hline \multirow[t]{5}{*}{ 病歴 } & 1年末満 & 1 & $3.2 \%$ \\
\hline & 1 年 3 年未満 & 2 & $6.5 \%$ \\
\hline & 3 年 5 年末満 & 5 & $16.1 \%$ \\
\hline & 5 年 10 年末満 & 7 & $22.6 \%$ \\
\hline & 10 年以上 & 16 & $51.6 \%$ \\
\hline
\end{tabular}

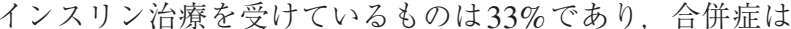
$16.1 \%$ に出現していた。 インターネットを利用したメールで のやり取りは全員が経験しており，そのうちスマホやタブ レット，パソコンによるSNS 利用は $35.5 \%$ であった。

\section{2 「糖尿病応援サイト」の利用状況}

「糖尿病応援サイト」への年間一人当たりの平均投稿回数 は, $49.0 \pm 45.6(\mathrm{SD})$ 回で, 29 回以下の人が $45.2 \%$, 次いで 30 回〜 59 回迄が $25.8 \%$ であった。年間一人当たり平均閲覧 回数は $97.0 \pm 69.5(\mathrm{SD})$ 回で, 150 回以上の人が $25.8 \%$ で, 次いで1〜29回，30５9回，60８9回がいずれも 19.4\% であった（図3）。対象者の間違った情報に対する専門家の 指摘は一度もなく，同病者間で答えられない内容に対する情 報提供や助言は 14 回であった

「糖尿病応援サイト」でのやり取りは，自分の興味あるも のを選択できるよう5つのコンテンツを設けた，開始当初は， 「サイト広場」「自己管理への思い」「食事」「運動」「くすり」 の順に利用されていたが, 経過に伴い, 内容を限定せず日々

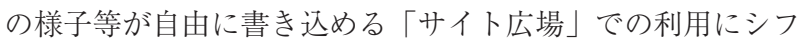
トしていった，投稿は，自己管理状況（食事や運動の工夫や 失敗談)，それに対する称賛や共感のやりとりが行われてお り，その他，季節情報や体験した介護の話等が語られていた。

やりとりの中で，間違った情報交換などはなく，新たな 治療薬への質問など応えられないものに関しては，専門家が 解答する対応が行なわれていた，投稿内容のやりとりの一部 を図4に示す。

\section{3 ネットワーク上でのコミュニケーションへの影響要因}

「糖尿病応援サイト」で情報交換や思いの共有等のコミュ ニケーションがどのように行われていたのかを分析した結 果，125コード (インタビューデータ), 22 サブカテゴリー, 9 カテゴリーが抽出された，カテゴリーとそれを構成するサ ブカテゴリーについては表2に示す。

以下，それぞれのカテゴリーについてカテゴリーを【】， サブカテゴリーを『』, コードをく >で表記する。また, （）に研究対象者を番号 $(\# 1 〜)$ で示す.

「糖尿病応援サイト」では,【交流による関係性の形成】に より，【自己管理への示唆】【人では得られない情報の入手】 【記録に残る情報】が得られていた。しかし，【相手の状況が

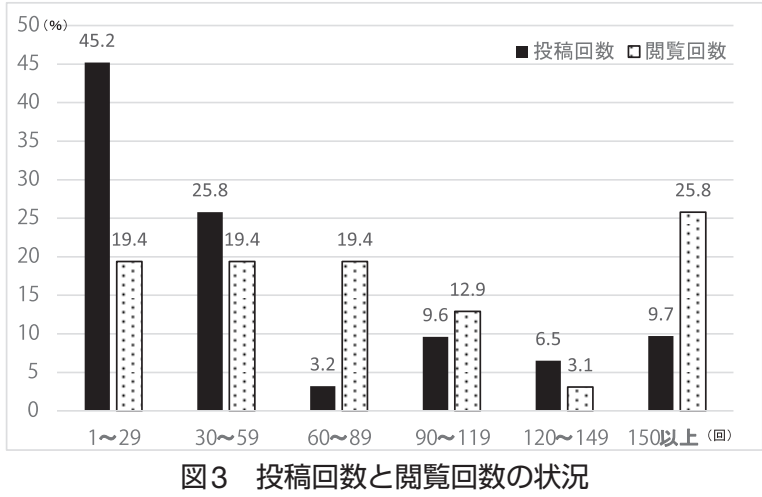




\begin{tabular}{|c|c|c|}
\hline i-ム & 月日 & コメント内容 \\
\hline$\# 2$ & •月5日 & 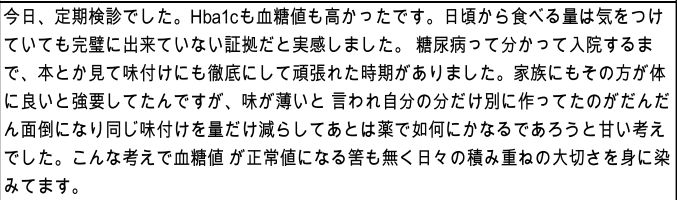 \\
\hline$\# 12$ & •月6日 & 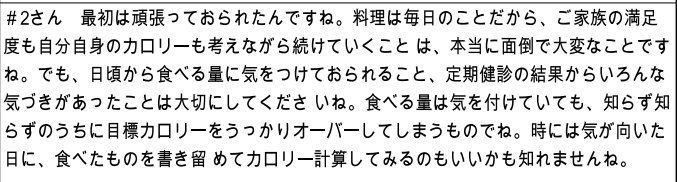 \\
\hline$\# 2$ & •月6日 & $\begin{array}{l}\text { 食べる量を決めていてもカロリー計算まで出来ていないので今度測ってみます。多分、 } \\
\text { 思ってるより多いとは思います。 }\end{array}$ \\
\hline 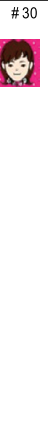 & •月6日 & 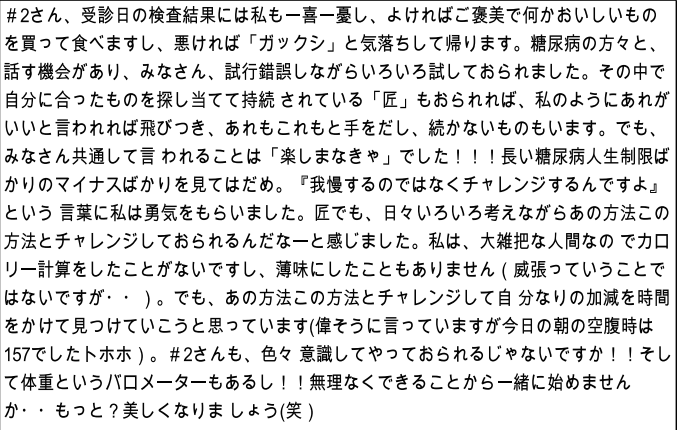 \\
\hline \#2 & •月6日 & 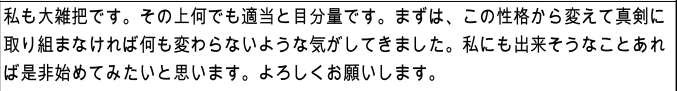 \\
\hline (27) & •月6日 & 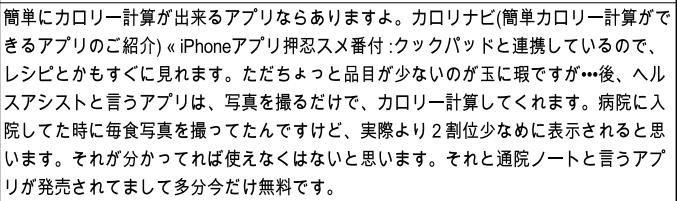 \\
\hline \#2 & ・脒6日 & 沢山の情報を有り難うございます。早速利用してみます。 \\
\hline
\end{tabular}

図4「サイト広場」の投稿内容の一部抜粋

わからない入りにくさ】や【会話の流れに乗れないことでの 入りにくさ】伝えることの躊躇】【自分なりの自己管理の確 立】【文字にする煩わしさ】がコミュニケーションに影響し ていた，以下，各々のカテゴリーについて述べる。

【交流による関倸性の形成】は，〈やり取りをしていると， 書いている内容や反応の仕方で，その人の人柄がなんとなく わかってくる. 全然会わないけど，やり取りすることで分か ることがたくさんある。交流がある事が楽しい $(\# 2)><$ 内容 としては，たわいもないことでいいと思うんです，それが 書けたら扔互いの人となりが分かるし $(\# 2)>$ との発言から,

取りとめない日常的な投稿の積及重齐が、『交流による親しみ やすさ』につながり，〈自分の書きたいことを書きます。 意見をもらえるとまた書こうという気になる (\#26) ><返信 が来ると元気がもらえる(\#3)><このサイトの話をもらった 時, 自分の周りに糖尿病の人がいないので, どんなふうに皆 さんしているのかと期待があった、いろいろな情報交換がで きる (\#23)>との発言から, 『返信への期待』が, さらなる情 報交換につながっていた.

【自己管理への示唆】では, くこの人こんなに頑張ってるん や. 私も頑張らないと, と思える (\#3) ><ちゃんとしたら下が るということが皆さんの意見から分かり参考になった $(\# 11)>$
表2 ネットワーク上でのコミュニケーションへの影響要因

\begin{tabular}{|c|c|c|c|}
\hline カテデリリー & サブカテゴリー & コード数 & 人数 \\
\hline \multirow{2}{*}{$\begin{array}{c}\text { 交流による関係性の } \\
\text { 形成 }\end{array}$} & 交流による親しみやすさ & 4 & 4 \\
\hline & 返信への期待 & 3 & 3 \\
\hline \multirow{3}{*}{ 自己管理への示唆 } & 自己管理への動機づけ & 4 & 4 \\
\hline & 自己管理の振り返り & 6 & 6 \\
\hline & 自己管理への共感 & 8 & 8 \\
\hline \multirow{2}{*}{$\begin{array}{c}\text { 一人デは得られない } \\
\text { 情報の入手 }\end{array}$} & 実践可能な情報の入手 & 6 & 6 \\
\hline & 体験を基盤とした情報の入手 & 5 & 5 \\
\hline 記録に残る情報 & いつでも見れる情報 & 3 & 3 \\
\hline \multirow{3}{*}{$\begin{array}{c}\text { 相手の状況が } \\
\text { 分からなないりにくさ }\end{array}$} & 相手の健康状態に合わせた支援のしにくさ & 4 & 3 \\
\hline & 相手の状況が分からない支援のしにくさ & 3 & 3 \\
\hline & 病気関連の結びつきによる楽しい会話のしにくさ & 3 & 2 \\
\hline \multirow{3}{*}{$\begin{array}{c}\text { 会話の流れに乗れない } \\
\text { 入りにくさ }\end{array}$} & 日常的な話題への入りにくさ & 8 & 8 \\
\hline & 時間経過に伴う入りにくさ & 6 & 5 \\
\hline & 関係性による入りにくさ & 5 & 3 \\
\hline \multirow{3}{*}{ 伝えることの躊躇 } & 衴テイブ発言への躊躇 & 7 & 6 \\
\hline & 当たり前の自己管理への躊躇 & 13 & 12 \\
\hline & 自慢に㠌わろ発言への躊躇 & 5 & 3 \\
\hline \multirow{2}{*}{$\begin{array}{c}\text { 自分なりの } \\
\text { 自己管理の確立 }\end{array}$} & それなりにできている自己管理 & 7 & 5 \\
\hline & 積極的な自己管理 & 4 & 4 \\
\hline \multirow{2}{*}{ 文字にする煩わささ } & 文字にする苦手意識 & 5 & 4 \\
\hline & 文章化できない煩わしさ & 5 & 4 \\
\hline \multicolumn{2}{|c|}{ その他(機器の操作性·精神的な余裕のなさ等) } & 10 & 6 \\
\hline
\end{tabular}

と，他者と比較することで『自己管理への動機づけ』になっ ていた。 さらに、くたた， みんなの意見を聞いて，自分はそ こまでやってないけど大丈夫かなと思うことはある（\#9）> <参加してみて，20年来の糖尿病であるが，甘く見ていた 部分があり, 甘く見てはいけないと感じた $(\# 2)>と$, 他者 との比較による『自己管理の振り返り』の機会となっていた. さらに, <でもみんなこんなことで悩んでるんや, 同じやと 思う $(\# 18)><$ くとなく自分がしていることを人もしてい るんだという安心が得られた（\#13）>と，他者との比較によ る『自己管理への共感』を抱いていた。

【一人では得られない情報の入手】は，＜参考になること があればやってみる（\#3）><最初はそうなんだ，というこ とをまねてみたり，極力血糖が上がらないように努力してい た，料理方法や食べ物は参考になった $(\# 11)><$ 自分でもで きそうなことは試している $(\# 26)>$ と, 『実践可能な情報の 入手』が行えていた，さらに，＜方にコロッケ食べたら血 糖がこれだけ上がっていたとか, こんなものあるよ，の紹介 とか・・参考になった。 それを見ることで，コロッケはダメ だなとか，わかる $(\# 2)><$ 計測の仕方．糖質 $1 \mathrm{~g}$ が $3 \mathrm{~g}$ 上昇 するとか参考になった（\#3）><炭水化物制限の重要性がサ イトを見てわかり理解できた $(\# 6)>$ な゙の発言から, 『体験 を基盤とした情報の入手』につながっていた.

【記録に残る情報】では, ICTを利用することで，＜書き 込みのいいところは後からでも見られるので, 何日か前か らさかのぼれる。言うだけでは忘れてしまう $(\# 8)>$ など, 『いつでも見られる情報』により, 時間が経過しても情報を 入手していた. 
しかし，【相手の状況がわからない入りにくさ】があり, く相手にどこまで突っ込んでいいのか分からない部分があ り，ここまで書くのも，と思う部分がある $(\# 4)><$ 簡単にこう したらとは言えない，人によってレベルがあるから $(\# 10)>$ と，『相手の健康状態に合わせた支援のしにくさ』が語られて いた。 さらに，〈自分なりには分析しているけど，人によって やり方も違うし，それをあえて書くほどでもないし（\#19）> との発言から,『相手の状況がわからない支援のしにくさ』や, くこのサイトは病気ネタだから, 共通の話題は病気のことだ け，環境や食べ物も違うから $(\# 8)><$ 病人同士が行うという マイナスの弱点があると思う。普通のフェイスブックだと楽 しい旅行の話などができるけど，このサイトは糖尿病でつな がれているので，やはり病気関連の話になる，そうなると， どこに行ったとか，そんなのを投稿するのもと思って（\#5）> と,『病気関連の結びつきによる楽しい会話のしにくさ』が あった。

【会話の流れに乗れない入りにくさ】では，＜例えばこん なことで悩んでいるとか，こんなことでみなさんの意見が 欲しいというテーマ性があれば。自分はこうしていると伝 えることはできる $(\# 4)><$ 日常なことなら, 流れがあるの で, 入りづらい. 知らない人の中での投稿は, 抵抗はないが, 何かテーマがあるとそのことについて話せばいいのでいつ でも入れると思う。このテーマについて，の方が入りやす い $(\# 6)>$ と曰常的な話題への入りにくさ』が語られ, く入りにくい. ちょっと間を空けると入っていいのかなと思 う. 突然何もないのに入ってもと思うと入りづらい $(\# 16)>$ くサイトにも流れがある，読んでないとなかなか流れに乗 れない。ちょっと離れて戻った時にどうなんだろう，入り づらい $(\# 17)>$ と『経過に伴う入りにくさ』や，〈途中か ら人が入ってきて投稿しにくくなった $(\# 4)><大$ 大体が, 3 人のやり取りなので, 途中から入りづらい $(\# 7)>$ など 『関係性への入りにくさ』による投稿のしにくさがあった

【伝えることの躊躇】では, <投稿内容ができなかったとか, 今日もダメだったなどの内容が多く参考にならなかった.もっ と，こうすれば出来たとか，これが効果があったなどあれば 参考になる（\#6)＞＜悪いことしか言えない，自分がきっちり 出来ていないから，意味ないことを話しても仕方がないし．

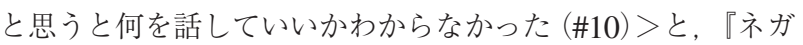
ティブ発言への躊踷』や，〈特別なことをしているのではな く, 一般にいいとされる炭水化物を抜くとか, 運動するとか やっているだけ・・午れを成功例として書くのもなと思っ ているうちに書けない，本当に誰でもやっていること，それ を自分なりに，気をつけているだけだから $(\# 15)>$ と『当た り前の自己管理への躊躇』が語られていた，そして，〈自分 の值がいいと，何となく自慢するようだし，悪いなあと思っ

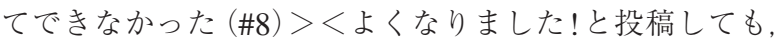
自慢するようで $(\# 10)>$ と『自慢にとられる発言への躊躇』 が利用のしにくさに影響していた。

【自分なりの自己管理の確立】は，＜介護で規則正しい生 活をしていたら, $\mathrm{Hb}(\mathrm{HbA1c})$ も下がってきたので, 努力せ
ずにできた。そういうことだったのかとわかった（\#11）> <今落ち着いているので，人の意見を聞かなくても自分なり にできているから $(\# 19)>$ との発言から『それなりにできて いる自己管理』やく食事に気を付け運動も時間をとるように 意識しながら体調管理に努めている。現状に問題を感じてい ないから，あまり見ていない $(\# 17)>$ な゙，『積極的な自己 管理』により他者の情報を必要としていない発言が聞かれた。

【文字にする煩わしさ】があり，〈みんなの投稿記事を見て いるのは参考になる。いろいろな意見も頂いた，たた，自分 が投稿するとなると話は別。サイトでは書くことが苦手とい うこともあった $(\# 12)><$ 言えるけど文字にするのは苦手. 文字にするまでに何回か書かないとうまく書けない $(\# 23)>$ と『文字にする苦手意識』やくこの前も，運動がやっぱりい いとか書きたかったけど，いざ書こうと思うと，どう書いて いいかわからない。一回下書き書いてじゃないと書けない. なので，そこまでして，と思う（\#16）>と『文章にできない 煩わしさ』が語られていた。 その他として, 機器の操作性や, 精神的な余裕のなさなどが語られていた。

\section{6. 考 察}

非対面式の糖尿病患者間のソーシャル・サポートシステム の構築のために, ネットワーク上でのコミュニケーションの 展開における影響要因について検討した。

\section{1 関係性の形成に向けた情報の共有}

一面識もない糖尿病患者同士が, 揭示板での取りとめな い日常的投稿のやり取りにより，その人となりがわかり， 『交流による親しみやすさ』や『返信への期待』に沿う, 【交流による関係性の形成】により双方向のコミュニケーショ ンが促進されていたと考えられる。ささらに，同じ経験を持つ 者同士の交流による関係性の形成が，『実践可能な情報の入 手』や『体験を基盤にした情報の入手』といった【一人では 得られない情報の入手】や，自己との対峙による『自己管理 の振り返り』や『自己管理への動機付け』といった【自己管 理への示唆】を得られたことが, コミュニケーションの促進 に繋がったのではないかと考える(図5参照).

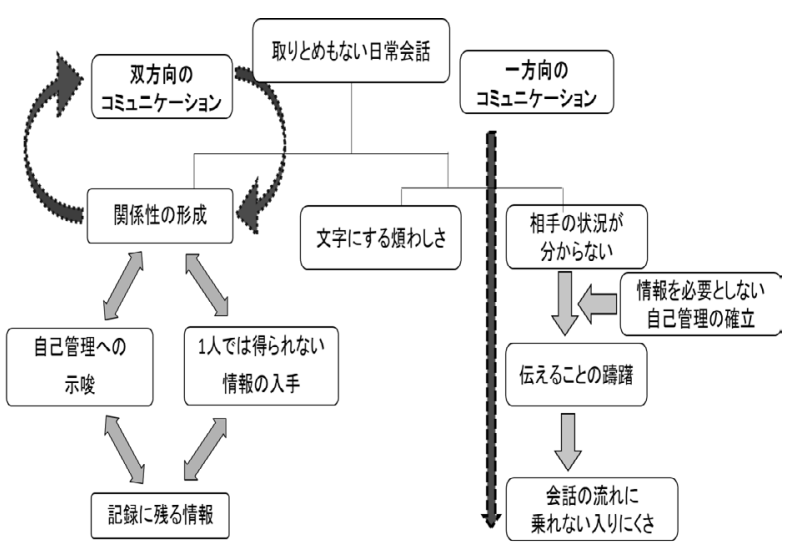

図5 コミュニケーション形成のプロセス 
一方で，＜相手にどこまで突っ込んでいいのか分からない 部分があり，ここまで書くのも，と思う部分がある>との発 言などの【相手の状況が分からない入りにくさ】やく意味な いことを話しても仕方がないし・・>＼cjkstart簡単にこうしたらい いといえない，人にもレベルがあるから>などの【伝えるこ との躊躇】があり, 特別な事を提供しなければという思いや, 相手に対する遠慮が，双方向のコミュニケーションを抑制 し, 関倸性が形成されないことで, 投稿のしにくさ温存とい う悪循環を引き起こしていた (図 5 参照).

三浦 [15］は，接触頻度が対人魅力に対して非常に大きな 効果を持ち, この接触の効果は, 一回一回のコミュニケーショ ンでは統計的には検出できないほど弱いが，何週間もの積み 重ねを通じて人間関係を大きく決定すると述べている，さら に，大坊 [16]は，人は，それぞれに得る経験は異なり， 自ずと獲得できる情報量には限りがある。そこで生じた情報 の落差や理解を補強し, また, 個人では不安定な判断の基盤 を, 自分となんらかの結びつきを持てる可能性のある他者と の関係の中に求めようとすると述べている.

本サイトは, 糖尿病患者同士の情報交換や思いの共有等の コミュニケーションの場であり, 相手に自分の思いや感情, 悩みを打ち明ける状況が生じやすいことから, お互いが気兼 ねなく発言できる関係性を形成することが重要であり，その ためには, 双方の状況を把握しあうことが大切である. 今回 は, 双方の情報として, 年齢や職業, 治療内容といった基本 的な内容を開示していた。 しかし, 糖尿病が生涯の疾患であ ることから, 病状や合併症等の変化に応じ, その時々の思い や関心事も左右される，そのことが，【相手の状況が分から ない入りにくさ】や【伝えることの躊躇】にも繋がっていた と考えられる。 今後は, このような状況の改善のために, お互いのことを把握できる情報提供の方法や，関係性を築く ための検討が必要である.

\section{2 長期的な自己管理を踏まえたコミュニケーション形成}

慢性疾患は，いったん発症すると病気そのものが完治する という状態はほとんどの場合望めないため, いかに病気と付 き合っていくかが課題となる。長期にわたり療養法や治療を 継続していくには, 特に糖尿病は, 自覚症状にそしく, 体感 しにくい病気であるため, 時間経過とともに食習慣や運動習 慣の改善を日々の生活の中で実現し，維持することの困難さ がある。さらに, 病気の慢性状態は長期間時間をかけて多様 に変化し, 上に向かう時や下に向かう時, 同じ状態を保つ時 があり, どの局面にあっても, 数週間から数か月の逆転現象 や平坦現象, 上昇現象や下降現象など絶えず変化を繰り返し ている [17-19].

<悪いことしか言えない. 自分がきっちり出来ていないか ら．意味ないことを話しても仕方がないし>という『ネガティ ブ発言への躊踷』や，〈本当に誰でもやっていること，それを 自分なりに気を付けているだけだからという『当たり前の 自己管理への躊躇』に代表されるような【伝えることの躊躇】 には, 長期的な継続が求められる自己管理下では, 短期的に
目立った改善がみられるわけではない慢性疾患の特徵が影響 している可能性も示唆される。一方で, くでもみんなこんな ことで悩んでるんや，同じやと思う ><何となく自分がして いることを人もしているんだという安心感が得られた>とい う発言は，長期的な自己管理の中で『自己管理への共感』や 『自己管理への動機づけ』に基づく【自己管理への示唆】に結 びつくコミュニケーションへとつながる可能性も窥える.

く例えばこんなことで悩んでいるとか, こんなことでみな さんの意見が欲しいというテーマ性があれば，自分はこうし ていると伝えることはできる $><$ 日常なことなら，流れがあ るので，入りづらい. 何かテーマがあるとそのことについて 話せばいいのでいつでも入れると思う>という発言から， 一進一退を繰り返し, 変動のある自己管理状況であっても, 同じ思いや興味・関心事等，共有できるテーマを意図的に 設定し, 参加者に投げかけることで, それをきっかけにコミュ ニケーションが促進され，ネガテイブ発言や当たり前の発言 であってもコミュニケーションの促進へと誘導していける可 能性があると考える，さらにそれにより，カテゴリーで抽出 された【会話の流れに乗れない入りにくさ】もある程度の解 消に繋がることが期待される.

\section{3 発言しやすいグループ構成の検討}

くでもみんなこんなことで悩んでるんや，同じやと思う＞ くなんとなく自分がしていることを人もしているんだという 安心が得られた>などの発言や，図4の「サイト広場」の投稿 内容の一部抜粋からも，受診結果の投稿をきっかけに，共感 や励ましが行われており，『自己管理への共感』が多かった (コード数 8 (表 2 参照)).このことから，同じ体験をしてい る集団であることで, 励ましや安心等, 自分の状況を理解し てくれる共感が得られる場となっていたといえる.

間野 [20）は，同一課題の克服という共通の目的をとおし て他者と心情を共有することが, 自尊心の回復や意識改革な どの学習効果を生み出す可能性を秘めていると述べている. さらに, プリース [21] は, オンライン上のソーシャル・サポー 卜は情報資源の提供とは別に, 重要な役割は共感である. 人はただ単に事実に基づく情報を探しているのではなく， 問題に苦しんでいる自分自身を確認し，同じょうに苦しんで いる人とコミュニケーションをしていると報告している. このことから, 非対面式であっても, 同じ状況にある他者の 存在が，生活習慣の改善に伴う，ストレスや孤独感の緩和に つながり，自尊心の支えになると考えられる．

松尾ら [22]は，ユーザーは自分の興味がより的確に表さ れたコミュニティを見つけ，そこに遷移していく、コミュニ テイが特化されるにしたがって人数が少なくなり，数十人 程度の小規模コミュニティになると，メンバーの顔が多少は わかり, 投稿数, メンバー数とも比較的居心地がよい領域と なると述べている. 今回, 31 人でのコミュニケーションは, 様々な年代や背景が異なることで, 幅広い情報収集や交換 の場に繋がると考えていた。しかし，【自己管理への示唆】 や【一人では得られない情報の入手】を述べていた人が 6 人 
程度であったことから（表2参照），全体での幅広い情報収 集や交換の場となっていたとは言い難い. 今後は, コミュニ ケーションを促進させる観点から, どのようなグループ形成 が適切なのか, 年代や病歴, 生活環境や健康段階等を考慮し, 興味関心に沿ったグループ構成やグループの規模等について 検討していく必要がある.

\subsection{ICT利用を促進する機能の選択}

平成 26 年版情報通信利用動向調査 [23]によると, ソーシャ ルメディアの利用率は, 若年層ほど利用率が高く, 60 歳以上は $22.3 \%$ との報告がある. 本研究の対象者は, 60 歳以上が $45.2 \%$ であり，SNSを利用したことがある人は $35.5 \%$ であった。

＜言えるけど文字にするのは苦手，文字にするまでに何回 か書かないとうまく書けない〉など, 自分の感情や情報を文 章に整理して伝える難しさや, 文字にして伝える難しさが情 報の授受に影響し，コミュニケーションの低下が関係の形成 を妨げていた，そのことが書きにくいという悪循環の連鎖を 引き起こしていたと推測できる，さらに，くこの前も，運動 がやっぱりいいとか書きたかったけど，いざ書こうと思う と, どう書いていいかわからない，一回下書き書いてじゃな いと書けない. なので, そこまでして, と思う>との発言は, 文字に対する煩わしさだけでなく，何をどう発言すればいい のかといった思いが, 参加へのためらいとなっていたと推測 できる，しかし，発言手段が文章である以上，自分の思いを 文章にすることや顔の見えないコミュニケーション方法は, 苦手意識のある人にとっては, 双方向のコミュニケーション のしにくさにつながるといえる.

近年, 伝わりにくい会話中の互いの表情や思いを伝える手 段として，エモティコン (顔文字) やスタンプ等の機能が利 用されている [16]. これらの機能を付加することで, 投稿 者の【返信への期待】にも応答したいと思う人の 1 つの方法 となり, それにより, 文字のみによる伝達の困難さをある程 度は軽減することができるのではないかと考える，利用者が 活発に利用することで情報が蓄積されサービスが向上する コミュニティシステムにおいては, 活動に際しての負荷をで きるだけとり下げることが重要になる，糖尿病患者の多く は，壮年期以降の高齢者が多いことを鑑みれば，高齢者でも 利用しやすい機能の選択や発言へのきっかけつくりが双方向 の交流につながるといえる。

\section{7.おわりに}

以上の結果から，一面識もない患者同士が，ソーシャル． サポートシステムを利用することで, 取りとめない日常的会 話からその人となりを理解し, 双方の交流により関係性を形 成できたことが, 一人では得られない情報の入手や, 自己管 理への示唆が得られる場となっていた，時間や状況の制約 により同病者からの支援が得られなかった人にとって, ソーシャル・サポートシステムは自己管理への示唆や情緒的 支援が得られる場であることから，プロトタイプとしての
可能性が示された。しかし，利用者が活発に利用することで 情報が蓄積され, 必要な情報を獲得するという観点からは, いくつかの改善すべき点が示唆された.

関係性の形成が基盤となるソーシャル・サポートシステム では，双方向のコミュニケーションによる関わりが重要であ り，コミュニケーションの促進のために，打互いの状況を 把握できるシステムの検討が必要である。そのためには, 対象者の年齢・性別・病歴・治療内容や生活環境だけでなく, 病状や疾病の受容段階, 病気に対する思いが分かるような, 例えば，数值化した表示方法を用いたり，同じような状況の 人と意図的にコミュニケーションが図れるように，管理者が 把握した上でグループ形成等の体制つくりが必要と考える. さらに，糖尿病の長期的な自己管理を踏まえたコミュニケー ション形成につながるテーマの設定など，患者の心理面を考 慮した発言しやすい状況の検討が必要である。また，興味関 心により情報交流が活発化する可能性があることから，共通 した興味関心がお互いのサポートに繋がると期待される。 そして, 糖尿病患者は高齢者が多いことから, 高齢者でも使 いこなせる操作性の検討や, 文字にする煩わしさを取り除き， かつ返信への期待に応えられるような，エモティコンやス夕 ンプ機能等を取り入れたシステムの改善が, 双方向の効果的 な支援に繋がるといえる。

本研究における今回の検討では, ネットワーク上でのコミュ ニケーションに影響を及ぼす可能性がある，糖尿病の治療内 容や健康レベル, 年齢等の違いによる分析や, SNS 利用経験, グループの構成や規模, さらに機器の操作性が投稿に及ぼす 影響について詳細な分析はできていない。今後は, 対象ユー ザー数を増やし，これらの詳細な分析を行うことで，ICTを 利用した糖尿病患者同士の更なる闘病への支援を強化してい けるものと考える.

\section{謝 辞}

本研究にあたりご指導いただきました, 四條畷学園大学 鈴木幸子教授に深謝いたします。そして何より，ご協力いた だいた患者の皆様，施設の皆様に心より感謝申し上げます. 本研究は, JSPS 科研費24234567の助成を受けたものです.

\section{参 考 文 献}

[1] Solomon P.: Peer support/peer provided services underlying processes, benefits, and critical ingredients, Psychiatric Rehabilitation Journal, 27(4), pp.61-72, 2004.

［2］藤永新子，大田博，石橋信江，東ますみ：糖尿病患者に対 するピア・サポートが自己管理行動と負担感に及ぼす影響 一患者会の有無による比較から一, 日本保健医療行動科学 学会誌, 30(2), pp.61-70, 2016.

［3］銘苅知美，宮城裕子，石川りみ子，伊牟田ゆかり：自己管 理を行う糖尿病患者がピアから受ける影響, 第41 回成人 看護学II論文集, pp.29-32, 2010. 
４4］小檜山佳正, 高橋一郎, 北村文恵他：糖尿病患者会におけ る食生活調査 - 行動変容段階および自己効力感調査一, 北海道文教大学研究紀要, 33, pp.89-97, 2009.

[5] 小野美穂, 高山智子, 草野恵美子, 川田智恵子：病者のピア · サポート機能の実態と精神的健康との関連一オストメイト を対象に一, 日本看護科学会誌, 27(4), pp.23-32, 2007.

[6] 日向野香織, 柴山大賀, 林啓子, 川口孝泰 : 競争意識を利 用した歩行継続支援システム - 遠隔看護の取り組み事例 慢性疾患患者のサポートー, 看護研究, 48 (2), pp.136-144, 2015.

[7] Stewart M., Davidson K., Meade D.: Group support for couples coping with a cardiac condition, J. Adv. Nurs, 33(2), pp.190-199, 2001.

[8] Michel Heisler, Sandeep Vijan, Fatima Makki, and John D. Piette: Diabetes Contorol With Reciorocal Support Versus Nurse Care Management, Annals of Internal Medicine, 153(8), pp.507-182, 2007.

［9］保坂隆：がん患者グループ療法のためのファシリテーター 養成講座の意義と実際 がん患者や家族が必要とする社会 的サポートやグループカウンセリングの有用性に関する研 究, 厚生労働科学研究費補助金 がん臨床研究事業 総合研 究報告書, pp.14-43, 2009.

[10］久保田晃生, 永田順子, 杉山眞澄 : ソーシャルサポートを 強化したグループ参加による減量プログラムの有効性, 日本公衆衛生誌, 55(5), pp.327-339, 2008.

[11］南村二美代：2 型糖尿病患者の血糖コントロールに及ぼす 負担感とソーシャルサポートの影響, 大阪府立大学看護学 部紀要, 17(1), pp.25-35, 2011.

[12］倉林則之, 山崎達也, 湯淺太一：ネットワーク・コミュニ ティにおける関心の類似性に基づいた知識共有の促進, 情報処理学会論文誌, 43(12), pp.3559-3670, 2002.

[13] C. Pope, N. Mays : 質的研究実践ガイド, 医学書院, 2001.

[14] B. Glaser, A. Strauss : データ対話型理論の発見・調査か らいかに理論をうみだすか, 新潮社, 1996.

[15] 三浦麻子, 森尾博昭, 川浦康至 : インターネット心理学の フロンティア, 誠信書房, p.113, 2009.

[16] 大坊郁夫：ネットワーク・コミュニケーションに扮ける対 人関係の特徵, 対人社会心理学研究, 2002 .

[17] 石井千有季, 山田和子, 森岡郁晴: 教育入院後に再入院 した 2 型糖尿病患者の特徵と再入院に至る要因, 日本看護 研究学会雑誌, 5(4), pp.25-35, 2012.

[18］中沢富枝：慢性病者のセルフケア能力と困難感からみた外 来看護の一考察 外来通院する成人期 - 老年期にある描写 の意識調査から, 山梨県立看護大学短期大学部紀要, 8(1), pp.77-87, 2003.

[19] Cobin, J.M., Strauss, A. : 軌跡理論にもとづく慢性疾患管 理の看護モデル，慢性疾患の病みの軌跡ーコービンとス卜 ラウスによる看護モデル（黒江ゆり子, 市橋記子, 寶田穂 訳), 医学書院, pp1-31, 1995.
[20］間野百子：セルフ・ヘルプ・グループによるサポートの特質 と展開, 生涯学習·社会教育学研究, 29, pp.35-44, 2004.

[21] Preece, J.: Empathic Communities balancing emotional and factual communication, Interacting with Computers, 12, pp.63-77, 1999.

[22] 松尾豊, 安田雪: SNSに扔ける関係形成原理 - mixiのデー夕 分析 -, 人工知能学会論文誌, 22(5), pp.531-541, 2007.

[23] 総務省：平成 26年情報通信利用動向調査, http://www.soumu.go.jp/johotsusintokei/statistics/statistics05. html, PDF (参照日 2015年 12 月 3 日).

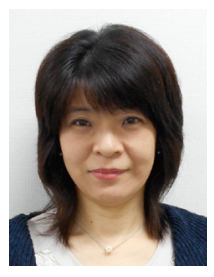

\section{藤永 新子 (正会員)}

2009 年 甲南女子大学大学院人文科学研究科 博士前期課程終了。修士 (社会・文化環境). 甲南女子大学看護リハビリテーション学部講 師を経て, 2015 年より四條睰学園大学看護 学部准教授. 現在, 兵庫県立大学大学院応用 情報科学研究科博士後期課程在学中. 糖尿病, ソーシャルサポー 卜の研究, 及び成人看護学教育に従事.

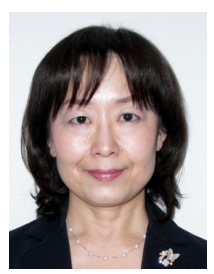

\section{東 ますみ (正会員)}

2008 年 兵庫県立大学大学院看護学研究科 看護学専攻博士後期課程単位取得後退学. 2011 年 兵庫県立大学大学院看護学研究科上 り博士 (看護学) 取得. 2004 年 兵庫県立大学 大学院応用情報科学研究科助教授. 2012 年 同教授. 2016 年より神戸女子大学看護学部教授. 看護情報学, 遠隔看護の研究に従事. 2011 年 日本遠隔医療学会優秀論文賞受 賞. 日本遠隔医療学会, 日本看護科学学会, 日本看護研究学会 などの会員

\section{石橋 信江 (正会員)}

甲南女子大学看護リハビリテーション学部看護学科老年看護学 領域講師. 専門: 老年看護学, 看護情報学. 免許.資格: 看護師, 保健師, 介護支援専門員, 医療情報技師, 現在は遠隔看護に関 する研究に取り組んでいる。兵庫県立大学大学院応用情報科学 研究科ヘルスケア情報科学コース看護情報学領域博士後期課程 在学中.

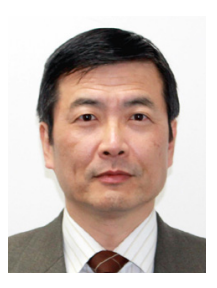

\section{西村 治彦 (正会員)}

1985 年 神戸大学大学院自然科学研究科博士 課程修了. 学術博士. 1989 年広島大学医学部 助手. 1990 年兵庫教育大学助教授, 1999 年 同教授. 2004 年より兵庫県立大学大学院· 応用情報科学研究科教授. 知能システム科学, 生体信号・ヘルスケア情報科学, 高信頼情報科学等の研究に従事. 2001 年 システム制御情報学会論文賞, 2010 年 日本感性工学会 技術賞受賞. IEEE, IEICE, IPSJ, SICE, ISCIE どの会員. 